\title{
PENENTUAN WILAYAH-WILAYAH SENTRA PENGEMBANGAN TERNAK KECIL DI PROVINSI NUSA TENGGARA TIMUR
}

\author{
Achmad Firman' ${ }^{1}$ dan Obed Haba Nono ${ }^{2}$ \\ ${ }^{1}$ Departemen Sosial dan Ekonomi Pembangunan Peternakan, Fakultas Peternakan, \\ Universitas Padjadjaran, J1. Raya Bandung Sumedang Km 21, Jatinangor Sumedang \\ ${ }^{2}$ Fakultas Peternakan Universitas Nusa Cendnana, Jl. Adisucipto, Penfui-Kupang, Nusa Tenggara Barat \\ Email: ahmadpedum@yahoo.com; obedhaba@gmail.com
}

\begin{abstract}
ABSTRAK. Penelitian ini dilaksanakan di Nusa Tenggara Timur yang bertujuan untuk menentukan wilayah-wilayah yang dapat dijadikan sentra bagi pengembangan ternak kambing, domba, dan babi. Data sekunder digunakan dalam penelitian ini untuk menentukan wilayah pengembangan ternak kecil tersebut. Analisis kuantitatif menjadi metode yang digunakan pada kajian ini. Hasilnya memperlihatkan bahwa (1) sentra pengembangan ternak kambing adalah di Kabupaten Sumba Timur, Kab. Timur Tengah Utara (TTU), Kab. Alor, Kab. Flores Timur, Kab. Sikka, Kab. Nagekeo, Kab. Manggarai Timur, dan Kab. Sabu Raijua; (2) pengembangan ternak domba terdapat di Kabupaten Rote Ndao dan Kabupaten Sabu Raijua; dan (3) pengembangan ternak babi terdapat di Kab. Sumba Barat, Kab. Kupang, Kab. Timur Tengah Selatan (TTS), Kab. Ngada, Kab. Sumba Tengah, Kab. Sumba Barat Daya, dan Kota Kupang.
\end{abstract}

Kata kunci: Sentra Pengembangan; Ternak Kecil; Kambing; Domba; Babi

\section{DETERMINATION OF SMALL LIVESTOCK DEVELOPMENT CENTRE IN EAST NUSA TENGGARA PROVINCE}

\begin{abstract}
The study has been held in East Nusa Tenggara Province that intended to determine the central regions for the development of goat, sheep, and pig. The secondary data was used in this research to determine the regional development for small livestock. The quantitative method was used in this research. The results reveal that (1) the centre of development of goat livestock is found in East Sumba Regency, Timur Tengah Utara (TTU), Alor, East Flores, Sikka, Nagekeo, East Manggarai, and Sabu Raijua; (2) development of sheep is found in Rote Ndao regency and Sabu Raijua regency; and (3) the development of pigs is placed in West Sumba regency, Kupang, East Middle South (TTS), Ngada, Sumba Tengah, Sumba Barat Daya, and Kupang city.
\end{abstract}

Key Words: Cemtral development; Small Livestock; Goat; Sheep; Pig

\section{PENDAHULUAN}

Provinsi Nusa Tenggara Timur merupakan provinsi di bagian Timur Indonesia yang memiliki banyak pulau. Tiap pulau memiliki keunikan geografisnya tersendiri. Akan tetapi secara umum, sektor pertanian memiliki peranan penting dalam perekonomian wilayah dan kehidupan masyarakat Nusa Tenggara Timur. Sektor pertanian merupakan sektor unggulan bagi Provinsi NTT karena kontribusi sektor ini bisa mencapai 28\% terhadap PDRB Provinsi NTT pada tahun 2018 dan 55\% penduduknya terserap bekerja di sektor pertanian (BPS Provinsi NTT, 2019). Hal ini semakin mempertegas bahwa sektor pertanian merupakan sumber kehidupan bagi sebagian besar masyarakat NTT.

Salah satu subsektor Pertanian yang juga berkembang di Provinsi NTT adalah sub sektor peternakan. Berdasarkan misi pembangunan dari provinsi ini, ada 6 (enam) tekad yang hendak dicapai, yaitu menjadi provinsi jagung, provinsi ternak, provinsi cendana, perikanan dan kelautan, pariwisata, dan provinsi koperasi. Ternak menjadi sasaran utama pembangunan di Provinsi NTT karena ternak menjadi komoditas yang penting bagi kehidupan masyarakat pertanian di NTT. Fungsi ternak di masyarakat NTT adalah berfungsi sebagai tabungan, sebagai mahar perkawinan, sebagai sumbangan untuk adat, dan sebagai persembahan untuk religi.

Berbagai ragam jenis ternak terdapat di NTT seperti sapi, kerbau, kuda, domba, kambing, dan babi. Semua jenis ternak besar dan kecil tersebut sebagai ternak yang paling dominan dipelihara oleh masyarakat pertanian di NTT. Ternak kambing dan domba adalah ternak ruminansia kecil yang sudah dikenal baik oleh masyarakat pertanian (Budiarsana, dkk., 2016). Kambing digemari untuk dipelihara karena termasuk ke dalam ruminansia kecil, pemeliharaannya mudah, berkembang biak dengan baik dan prolific, pertumbuhan anaknya cepat, dan daya adaptasi terhadap kondisi agroekositem suatu tempat baik (Sarwono, 2007 dalam Budiarsana, dkk., 2016;). Domba adalah ternak yang mampu beradaptasi dengan lingkungannya dengan baik serta mampu memakan hijauan yang nilai nutrisinya rendah, tahan terhadap penyakit dan parasit tertentu, bersifat prolific (beranak lebih dari satu ekor), capaian periode dewasa kelamin relatif cepat, serta dapat kawin setiap saat (FAO, 2002; Jarmuji, 2010). Di samping itu, ternak domba memiliki peranan penting di dalam kehidupan petani (Suryadi, dkk., 2016). Adapun ternak babi memiliki potensi yang baik 
dalam pengembangan usaha dan membuka lapangan kerja (Ariana, dkk., 2014).

Pada masyarakat NTT, domba, kambing, dan babi merupakan ternak peliharaan yang menjadi bagian dari kehidupan petani di NTT. Kambing merupakan ternak unggulan di Kabupaten Timor Tengah Selatan, bahkan memberikan sumbangan protein hewani bagi masyarakat lokal maupun di luar Kabupaten Timor Tengah Selatan. Ternak kambing menjadi ternak kecil yang potensial untuk dikembangkan di Kabupaten Timor Tengah Selatan (Pemda Kabupaten Timor Tengah Selatan, 2019). Keberadaan ternak domba di Nusa Tenggara Timur tidak menyebar merata, hanya ada di beberapa pulau tertentu saja, seperti Pulau Sabu dan Pulau Raijua. Ternak domba yang terkenal di kedua pulau tersebut adalah domba ekor gemuk (DEG) (Riwu, 2016). Ciri fenotipik domba adalah memiliki bulu putih dan hitam atau campuran keduanya, domba jantan berekor gemuk sedangkan domba betina sebaliknya, dan dalam satu kelahiran menghasilkan 1 sampai 2 ekor (Deny, 2016). Khususnya di Pulau Sabu, asal mula keberadaan domba ekor gemuk dibawa oleh Belanda pada awal abad ke 20. Domba ekor gemuk telah berkembang dan beradaptasi dengan baik di Pulau Sabu. Oleh karena keterisolasian Pulau Sabu mengakibatkan tingkat inbreeding domba tersebut tinggi (Riwu, 2016). Domba ekor gemuk telah menjadi bagian adat di pulau tersebut dan memiliki nama daerah "Ki' iJawa" atau domba Jawa. Pengembangan ternak domba ekor gemuk di pulau ini terdapat di Kabupaten Sabu Raijua. Pengembangan ternak di domba di kabupaten tersebut kurang mendapat perhatian yang dikarenakan terisolasinya pulau tersebut. Pulau Sabu dan Pulau Raijua (Kabupaten Sabu Raijua) merupakan pulau terpisah yang hanya dapat ditempuh dengan kapal laut dan pesawat terbang. Kondisi ini menyebabkan pengembangan ternak domba ekor gemuk menjadi terhambat akibat permasalah geografis. Dampak turunannya adalah jumlah populasi domba terus semakin berkurang.

Ada 8 species babi di dunia dan Indonesi mempunyai 5 spesies dari ke 8 spesies tersebut (Rothschild et al. 2011), salah satunya berada di NTT (Suwardi dan Thalib, 2015). Oleh karena kultur sosial masyarakat yang didominasi oleh beragama non muslim, ternak babi memiliki tempat tersendiri di sebagian masyarakat sehingga pasarannya cukup baik, serta dukungan kultur sosial yang menggunakan ternak babi di dalam setiap moment perayaan adat atau keagamaan, maka sangat wajar apabila ternak babi tersebar di NTT (Wea, 2016). Akan tetapi, ternak babi bisa saja terjadi kepunahan di NTT jika masyarakat NTT lebih mementingkan ternak babi impor dibandingkan dengan ternak babi lokal (Suwardi dan Thalib, 2015). Oleh karena itu, peternak babi memiliki peranan penting di dalam mempertahankan dan meningkatkan pengembangan peternakan babi. Keberlanjutan usaha peternakan babi di NTT masih dapat dipertahankan karena memiliki peranan penting bagi keluarga dan keagamaan.

Berdasarkan data BPS Provinsi NTT, perkembangan jumlah ternak kecil, yaitu kambing, domba, dan babi masing-masing sebanyak 674.227; 67.579, dan 2.073.446 ekor pada tahun 2017 (BPS NTT, 2018). Ternak babi menjadi ternak yang mendominasi ternak kecil di NTT. Ternak babi tersebar merata di seluruh kabupaten/kota di NTT. Urutan ke dua populasi ternak kecil terbanyak adalah ternak kambing. Ternak ini mulai menjadi primadoma masyarakat NTT karena mampu memberikan kehidupan bagi masyarakat pertanian. Sistem pemeliharaan ternak ini tidak begitu sulit bagi masyarakat NTT dan penyebarannya cukup merata atau di seluruh kabupaten/ kota terdapat ternak ini. Akan tetapi, publikasi penelitian ternak kambing sangat jarang sekali di NTT sehingga sitasi literaturnya untuk kajian ini sangat sedikit tentang ternak kambing.

Adapun ternak domba merupakan ternak ruminasia kecil yang mulai digemari untuk dipelihara. Ternak ini belum merata tersebar di seluruh kabupaten/kota. Kabupaten Rote Ndao dan Sabu Raijua merupakan kabupaten dengan pemeliharaan kambing terbesar di Provinsi NTT. Pembahasan pengembangan domba sangat jarang sekali dilakukan di wilayah NTT karena wilayah ini lebih cenderung mengembangkan ternak babi. Oleh karena itu, ternak domba penyebarannya tidak merata di provinsi ini.

Berdasarkan informasi potensi ternak yang diuraikan di atas, perencanaan pengembangan sentra peternakan ternak kecil di suatu wilayah harus didekati dengan konsep-konsep wilayah. Pengembangan sentra ternak kecil di NTT dalam rangka pengembangan ekonomi di daerah. Pengembangan ekonomi di wilayah adalah proses pembangunan di daerah yang melibatkan pemerintah setempat, swasta, masyarakat, dan pelaku lainnya yang terlibat didalamnya mengelola berbagai sumberdaya dan menjalin kemitraan antara pemerintah daerah dengan badan usaha serta masyarakat untuk menciptakan lapangan usaha dan mengkatalisator penumbuhan ekonomi dalam wilayah tersebut (Arsyad, 2005 yang dikutip oleh Susanto, 2014).

Pendekatan konsep wilayah ini sering digunakan oleh para perencana untuk meningkatkan potensi wilayah. Hal yang sering muncul di dalam permasalahan perencanaan pembangunan adalah penentuan prioritas pembangunan, yaitu sektor atau wilayah. Perencanaan pembangunan terbaik adalah dengan menggabungkan kedua prioritas tersebut, yaitu pembangunan sektoral/komoditas dan wilayah, namun hal ini sangat sulit terjadi karena keterbatasan data dan informasi di masing-masing wilayah. Rencana pembangunan yang dilakukan dalam rangka 
pengembangan wilayah yang ditumpu oleh pengembangan sektor-sektor unggulan menjadi arah pembangunan yang hendak dicapai oleh pengampu kebijakan di wilayah. Dengan demikian pendekatan pembangunan wilayah selalu mengkaitkan dimensi sektoral dengan dimensi spasial (Firman, 2003). Keseimbangan pembangunan regional di dalam perencanaan pembangunan harus menitikberatkan pada kemampuan sumber daya yang dimiliki dan harus dimanfaatkan secara efisien, tertib, aman dan berkelanjutan agar dapat dimanfaatkan oleh generasi berikutnya (Riadi, 2000).

Pada pendekatan sektoral, pertanyaan yang muncul adalah sektor mana yang harus dibangun agar tujuan pembangunan bisa dicapai (Eliza, 2017). Adapun pendekatan regional bertumpu pada wilayah mana yang akan dijadikan prioritas untuk mencapai tujuan pembangunan, setelah itu sektor apa yang dapat dibangun di wilayah tersebut. Akan tetapi, pendekatan wilayah sering digunakan untuk kepentingan-kepentingan lainnya, seperti pengembangan wilayah tertinggal, terisolasi, atau terpencil. Oleh karena itu, pendekatan sektoral dan wilayah menjadi dua pendekatan yang terbaik dalam kerangka totalitas. Namun demikian dengan berbagai kompleksitas permasalahan yang dihadapi dalam penentuan wilayah/ sektor/komoditas unggulan, diperlukan berbagai pendekatan analisis untuk mereduksi permasalahanpermasalahan terasebut. Di sisi lain, ketersediaan data untuk kebutuhan analisis menjadi kendala utama di daerah karena tidak adanya data yang up to date.

Pendekatan analisis regional menjadi satu kesatuan yang tidak terpisahkan dari rencana pengembangan wilayah dan sektor. Analisis regional digunakan untuk memudahkan pengambil keputusan dalam merencanakan pembangunan wilayah. Hasil-hasil analisis wilayah diintrepetrasikan untuk menentukan wilayah dan atau sektor apa yang akan dikembangkan di kawasan tersebut. Pendekatan analisis wilayah dapat diimplementasikan ditingkat komoditas, khsususnya pengembangan ternak kecil di Provinsi Nusa Tenggara Timur.

Ada beberapa pendekatan analisis dalam penentuan sektor atau komoditas unggulan di suatu wilayah, yaitu (1) Keunggulan komparatif (comparative advantage) suatu wilayah didekati dengan pendekatan Location Quotient (LQ), yaitu analisis yang umum yang biasa digunakan dalam penentuan model ekonomi basis (Sapriadi dan Hasbullah, 2015; Widjaya, 2012). Ekonomi basis memiliki peran yang cukup penting sebagai katalisator utama pertumbuhan regional karena langsung berkitan dengan permintaan barang dan jasa dari luar daerah (Adisasmita, 2005; Arsyad, 2005); (2) Keunggulan kompetitif (competitive advantage) didekati dengan pendekatan Shift Share (SS). Analisis ini dipakai untuk mengetahui dinamika perubahan/pergeseran sektor di suatu wilayah.
Analisis ini mengasumsikan bahwa adanya perubahan aktivitas produksi di suatu wilayah dibagi ke dalam tiga hal, yaitu pertumbuhan ekonomi, pengaruh pergeseran proporsional, dan pergeseran diferensial atau competitive advantage yang semuanya dibandingkan antara wilayah satu perekonomian kecil dengan wilayah dengan perekonomian yang besar (Adisasmita, 2005; Arsyad, 2005); dan (3) Analisis Tipologi Klassen merupakan metode analisis ekonomi wilayah yang menggabungkan dua analisis sebelumnya, yaitu LQ dan SS. Dengan dua pendekatan tersebut, Klassen membaginya menjadi 4 kuadran, yaitu jika sektor itu maju dan tumbuh cepat (Kuadran I); sektor itu maju namun tertekan (Kuadran II); sektor potensial (Kuadran III); dan sektor relatif tertinggal (Kuadran IV) (Syafrizal, 2008 dalam Widjaya, 2012).

Kelebihan dari penggunaan metode LQ adalah rumusnya yang sederhana dan mudah mengaplikasikannya (Hendayana, 2003). Selanjutnya dijelaskan juga bahwa kelemahan dari penggunaan metode LQ adalah (1) dituntut akurasi data, jika data tidak tersedia dan tidak akurat maka akan menghasilkan analisis yang bias sehingga diperlukan validasi data terlebih dahulu untuk menghindari bias; (2) delinasi wilayah kajian, yaitu kriteria wilayah dan ruang lingkupnya sering tidak jelas, hal ini dapat menimbulkan kesalahan dalam penentuan wilayah; (3) analisis ini bersifat kaku dan hanya mengilustrasikan satu periode saja, sehingga di tahun yang akan datang belum tentu sektor tersebut menjadi unggulan atau sebaliknya (Hendayana, 2003; Sambodo, 2002). Menurut Bappeda Kutai Kartanegara (2008) menyebutkan bahwa kelebihan dari analisis shift share adalah (1) mampu memberikan ilustrasi perubahan terhadap struktur ekonomi; (2) mudah dalam mengaplikasikan model analisis ini; (3) memberikan gambaran perubahan struktur ekonomi dan pertumbuhannya. Adapun kelemahan analisis ini, adalah: 1). Pemanfaatannya terbatas hanya untuk analisis ex-post. 2). Permasalahan acuan yang berkaitan dengan homothetic change, jika tatau ( $t+1)$ tidak dapat diuraikan dengan jelas. 3) Kesulitan mendapatkan data. 4). Kelemahan berikutnya adalah tidak cocok sebagai alat pendugaan di masa depan karena tidak konstan antar periodenya. 5). Tidak ada keterkaitan antar daerah ataupun antar sektor.

Kebijakan pembangunan NTT yang mengarah pada provinsi ternak, diarahkan pada pengembangan ternak kecil menjadi salah satu prioritas pengembangannya. Pengembangan sentra ternak kecil lebih ditekankan pada wilayah-wilayah yang akan dijadikan sumber-sumber pengembangan bagi ternak-ternak kecil tersebut, di mana penentuannya didasarkan pada pendekatan analisis wilayah atau regional. Penentuan ternak kecil unggulan dan wilayah-wilayah mana yang akan dijadikan sumber pengembangan didasarkan pada keuntungan komparatif dan kemampuan kompetitif dari ternak-ternak kecil 
tersebut. Tujuan daripenelitianiniadalahuntukmenentukan ternak kecil yang memiliki potensi, dan wilayah-wilayah mana yang menjadi sentra-sentra pengembangan ternak kecil di Provinsi NTT. Analisis yang digunakan dalam riset ini menggunakan tiga pendekatan untuk menentukan pengembangan wilayah, yaitu analisis Location Quotien, Shift Share, dan Tipologi Klasen. Dengan ketiga analisis tersebut dapat dipetakan wilayah-wilayah mana yang menjadi unggulan bagi ternak kecil di Provinsi NTT. Hasil studi ini diharapkan bisa menjadi salah satu pertimbangan perencanaan pembangunan ternak domba, kambing, dan babi di NTT.

\section{METODE}

Objek penelitian yang digunakan adalah data dan informasi yang relevan dengan penentuan komoditas unggulan ternak kambing, domba, dan babi di Provinsi Nusa Tenggara Timur.

Metode penelitian ini menggunakan metode kuantitatif dekriptif. Metode ini mendeskripsikan berbagai hasil analisis data sekunder yang diperoleh dari instansi terkait dengan penelitian, seperti Badan Pusat Statistik Provinsi NTT dan Dinas Peternakan Provinsi NTT.

Teknik pengumpulan data studi ini dilakukan melalui situs Badan Pusat Statistik (2018) dan laporan Dinas Pertanian Provinsi Nusa Tenggara Timur (2018) dan data lainnya yang relevan dengan penelitian.

Ada tiga analisis untuk menentukan komoditas unggulan ternak kecil, yaitu:

a. Analisis Location Quotient (LQ) diformulasikan sebagai berikut (Silaban, dkk., 2015):

$$
\begin{array}{r}
\mathbf{L Q}=\mathbf{V i} / \mathbf{V t} \\
\mathbf{Y i} / \mathbf{Y t}
\end{array}
$$

Di mana:

Vi : populasi ternak kecil i pada tingkat kabupaten/kota $\mathrm{Vt}$ : total populasi ternak kecil di tingkat provinsi Yi : populasi ternak kecil i di tingkat nasional Yt : total populasi ternak kecil di tingkat nasional Keterangan:

- Nilai LQ $=0$; ternak kecil i sama dengan wilayah lainnya

- Nilai LQ > 1; ternak kecil i adalah ternak unggulan wilayah

- Nilai LQ < 1; ternak kecil i bukan ternak basis/unggulan wilayah.

b. Formulasi Shift Share (SS) sebagai berikut:

$\mathrm{Dij}=\mathrm{Nij}+\mathrm{Mij}+\mathrm{Cij}$

$\mathrm{Nij}=\mathrm{Eij} \cdot \mathrm{rn}$

$\mathrm{Mij}=\operatorname{Eij}(\mathrm{rin}-\mathrm{rn})$

$\mathrm{Cij}=\mathrm{Eij}(\mathrm{rij}-\mathrm{rin})$ dimana: $\mathrm{i}=$ komoditas ternak kecil yang diteliti; $\mathrm{j}$ $=$ variabel (peubah) regional yang diteliti; $\mathrm{Dij}=$ perubahan (delta) ternak kecil i di wilayah j; $\mathrm{Nij}=$ pertumbuhan ternak kecil i di wilayah j; Mij = Bauran ternak kecil i di wilayah j; $\mathrm{Cij}=$ Keunggulan kompetitif ternak kecil i di wilayah j; Eij = total populasi ternak kecil i di wilayah $\mathrm{j}$; rij = laju pertumbuhan ternak kecil $\mathrm{i}$ di wilayah $\mathrm{j}$; rin = laju pertumbuhan ternak kecil i di wilayah n; rn= laju pertumbuhan populasi ternak kecil di wilayah n. Hasil dari analisis SS terbagi atas dua, yaitu SS (+) berarti ternak potensial di suatu wilayah, sedangkan SS (-) berarti ternak tidak potensial di suatu wilayah.

c. Tipologi Klassen sebagai alat analisis regional yang merupakan gabungan dari LQ dan SS yang disusun dalam suatu kuadran sebagai berikut:

1. Kuadran I adalah Ternak Kecil (i) maju dan tumbuh pesat yang ditandai dengan LQ $>1$ dan $\mathrm{SS}(+)$

2. Kuadran II adalah Ternak Kecil (i) maju tapi tertekan yang ditandai dengan $\mathrm{LQ}<1$ dan SS (+)

3. Kuadran III adalah Ternak Kecil (i) potensial untuk dikembangkan yang ditandai dengan LQ $>1$ dan SS (-)

4. Kuadran IV adalah Ternak Kecil (i) tertinggal dari wilayah lainnya yang ditandai dengan $\mathrm{LQ}<1$ dan SS $(-)$.

Semua analisis di atas harus terlebih dahulu menyeragamkan satuan dari ternak. Data yang tersedia untuk populasi ternak adalah dengan satuan ekor. Oleh karena itu, untuk penyeraman ukuran ternak digunakan animal unit (satuan ternak) dengan ukuran sebagai berikut: - $\quad$ Satuan ternak (ST) untuk domba, kambing dan babi di mana 1 ekor ternak kecil tersebut setara dengan 0,065 ST (Thahar dkk, 2003 dalam Juarini dkk, 2011).

\section{HASIL DAN PEMBAHASAN}

Perkembangan populasi ternak kambing, domba, dan babi di Provinsi Nusa Tenggara Timur dapat dilihat pada Gambar 1.

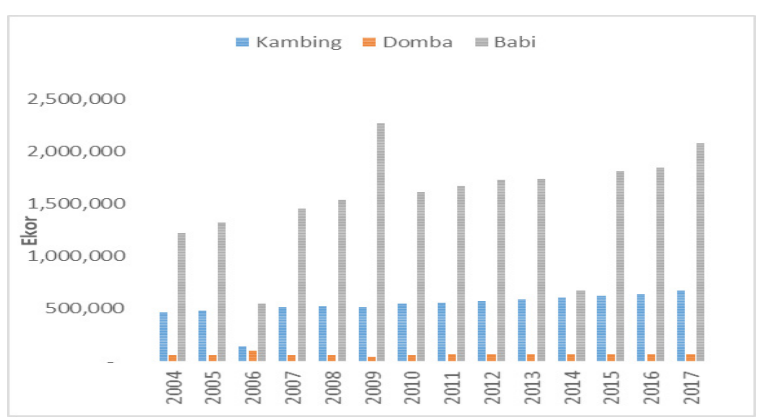

Gambar 1. Perkembangan Populasi Ternak Kecil di Provinsi NTT 
Gambar 1 di atas mengilustrasikan seluruh populasi ternak kecil mengalami peningkatan. Peningkatan yang signifikan terjadi pada ternak babi dan domba. Pada tahun 2004, populasi ternak babi sebanyak 1,2 juta ekor sedangkan pada tahun 2017 menjadi sebanyak lebih dari 2 juta ekor. Adapun ternak kambing sebanyak lebih dari 460 ribu ekor di tahun 2004 meningkat menjadi lebih dari 674 ribu ekor di tahun 2017. Ternak domba menjadi ternak yang belum dominan dipelihara oleh masyarakat petani di provinsi ini karena ternak domba belum membudaya di Provinsi NTT.

\section{Penentuan Unggulan Ternak Kambing di Provinsi NTT}

Hasil analisis LQ dan SS untuk ternak kambing dapat dilihat Tabel 1. Jumlah kabupaten yang memiliki nilai LQ > 1, terdapat 11 kabupaten. Kabupaten Lembata merupakan kabupaten dengan nilai LQ tertinggi dibandingkan dengan wilayah lainnya, disusul oleh Kabupaten Sabua Raijua, Flores Timur, dan Timur Tengah Utara. Adapun nilai LQ terendah terdapat pada Kabupaten Sikka dan Nagekeo. Nilai LQ di atas satu artinya wilayah tersebut memiliki kekuatan komparatif, yaitu ternak kambing telah menjadi komoditas yang telah membudaya di masyarakat.

Hasil analisis SS untuk ternak kambing di beberapa wilayah di Provinsi NTT dapat dilihat di Tabel 1. Pada tabel tersebut wilayah-wilayah yang memiliki SS $(+)$ untuk ternak kambing terdapat 17 wilayah. Nilai SS yang terbaik untuk ternak kambing adalah di Kabupaten Timor Tengah Utara dengan nilai SS sebesar 0,63, yang selanjutnya disusul oleh Kabupaten Belu, Kabupaten Sumba Barat Daya, Kabupaten Kupang, dan Kabupaten Sabu Raijua. Ternak kambing di kabupaten-kabupaten tersebut lebih memiliki keunggulan kompetitif dibandingkan dengan kabupaten/kota lainnya di Provinsi NTT yang bernilai SS (-).

Tabel 1. Hasil Analisis LQ dan SS Ternak Kambing

\begin{tabular}{lcc}
\hline \multirow{2}{*}{ Kabupaten/Kota } & \multicolumn{2}{c}{ Nilai } \\
\cline { 2 - 3 } & SS $(+)$ & LQ $(>1)$ \\
\hline Sumba Barat & 0,03 & \\
Sumba Timur & 0,07 & 1,32 \\
Kupang & 0,57 & \\
Timor Tengah Selatan & 0,03 & \\
Timor Tengah Utara & 0,63 & 1,47 \\
Belu & 0,31 & \\
Alor & 0,03 & 1.26 \\
Lembata & & 1.96 \\
Flores Timur & 0,03 & 1.61 \\
Sikka & 0,03 & 1.24 \\
Ende & & 1.27 \\
Ngada & 0,03 & \\
Rote Ndao & 0,03 & 1,25 \\
Sumba Tengah & 0,03 & \\
Sumba Barat Daya & 0,39 & \\
Nagekeo & 0,03 & 1,24 \\
Manggarai Timur & 0,03 & 1,39 \\
Sabu Raijua & 0,19 & 1,77 \\
Kota Kupang & 0,03 & \\
\hline
\end{tabular}

Keterangan: SS bernilai positif dan LQ lebih dari satu.
Berdasarkan hasil kedua analisis sebelumnya dapat dipetakan wilayah-wilayah mana yang menjadi wilayah unggulan untuk ternak kambing di Provinsi NTT. Analisis Tipologi Klasen menjadi salah satu analisis yang memadukan hasil dari LQ dan SS. Hasil analisis dari Tipologi Klasen ini dapat menentukan wilayah yang memiliki daya komparatif dan kompetitif dibandingkan dengan wilayah-wilayah lainnya. Hasil analisis Tipologi Klassen adalah sebagai berikut:

Kuadran I (SS (+) dan LQ > 1) terdiri dari wilayahwilayah Kabupaten Sumba Timur, Manggarai Timur, Alor, Sikka, Nagekeo, Timor Tengah Utara, Flores Timur, Sabu Raijua.

1. Kuadran II (LQ $<1$ dan SS (+)) terdiri dari wilayahwilayah Kabupaten Kupang, Belu, Ngada, Sumba Tengah, Sumba barat daya, Timor Tengah Selatan, Sumba Barat, Kota Kupang.

2. Kuadran III (LQ> 1 dan SS (-)) terdiri dari wilayahwilayan Kabupaten Lembata, Ende

3. Kuadran IV (LQ $<1$ dan SS (-)) terdiri dari wilayahwilayah Kabupaten Manggarai, Manggarai Barat

Berdasarkan hasil analisis tersebut, wilayah-wilayah unggulan untuk ternak kambing adalah Kab. Sumba Timur, Kab. Timor Tengah Utara (TTU), Kab. Flores Timur, Kab. Sikka, Kab. Nagekeo, Kab. Manggarai Timur, Kab. Alor, dan Kab. Sabu Raijua atau wilayah-wilayah yang berada di Kuadran I dengan nilai LQ $>1$ dan SS (+). Ke delapan kabupaten tersebut merupakan wilayah yang terpilih yang dapat menjadi wilayah pengembangan ternak kambing karena memiliki comparative dan competitive advantage. Dengan demikian. Organisasi Pemerintah Daerah (OPD) Provinsi NTT yang menangani peternakan dapat mempertimbangkan untuk menetapkan ke delapan kabupaten tersebut sebagai wilayah pengembangan ternak kambing di NTT. Hasil pemetaan ini juga dapat dijadikan rujukan untuk penyusunan Rencana Tata Ruang Wilayah (RTRW) Provinsi NTT. Berdasarkan Perda Provinsi NTT No. 1 Tahun 2011 tentang RTRW Provinsi NTT Tahun 2010-2030, pada pasal 30 hanya dijelaskan bahwa tentang kawasan peternakan. Penjelasan kawasan peternakan dan wilayahnya tidak dijelaskan di dalam RTRW tersebut. Dengan demikian diharapkan hasil penelitian ini bisa dijadikan sebagai salah satu acuan untuk penetapan kawasan peternakan khususnya ternak kecil, yaitu komoditas kambing di Provinsi Nusa Tenggara Timur.

\section{Penentuan Unggulan Ternak Domba di Provinsi NTT}

Hasil analisis SS dan LQ untuk ternak domba diuraikan pada Tabel 2. Hasil analisis LQ menujukkan bahwa hanya terdapat 2 wilayah yang merupakan basis ternak domba, yaitu Kabupaten Rote Ndao dan Kabupaten 
Sabu Raijua. Ternak domba bukan merupakan ternak unggulan di wilayah NTT namun keberadaannya menjadi salah satu komoditas yang menjadi sumber kehidupan bagi peternak di ke dua kabupaten tersebut. Nilai LQ lebih dari 1 pada kedua kabupaten tersebut didasarkan pada pengembangan ternak domba telah dimulai sejak awal tahun 2000 yang dikembangkan oleh Belanda, khususnya di Pulau Sabu dan Raijua. Oleh karena itu, populasi ternak domba lebih dominan berada di kedua pulau tersebut. Domba yang banyak dikembangkan adalah domba ekor gemuk.

Adapun hasil analisis SS dapat dilihat pada Tabel 2. Berbeda dengan hasil perhitungan LQ, hasil analisis SS memperlihatkan bahwa wilayah-wilayah yang memiliki SS (+) untuk ternak domba ada 10 wilayah. Nilai SS yang terbaik untuk ternak domba adalah di Kabupaten Kupang dengan nilai SS sebesar 0,17. Ternak domba di Kabupaten Kupang lebih memiliki keunggulan kompetitif dibandingkan dengan kabupaten/kota lainnya karena memiliki nilai SS lebih besar. Perhitungan ini memastikan bahwa ternak domba memmiliki nilai yang kompetitif dan dapat dijadikan sebagai ternak ekspor ke wilayah lainnya.

Tabel 2. Hasil Analisis SS dan LQ pada Ternak Domba

\begin{tabular}{lcc}
\hline \multirow{2}{*}{ Kabupaten/Kota } & \multicolumn{2}{c}{ Nilai } \\
\cline { 2 - 3 } & SS (+) & LQ (>1) \\
\hline Sumba Timur & 0.01 & \\
Kupang & 0.17 & \\
Lembata & 0.01 & \\
Flores Timur & 0.01 & \\
Sika & 0.01 & \\
Ngada & 0.01 & \\
Rote Ndao & 0.01 & 8,79 \\
Nagekeo & 0.01 & \\
Sabu Raijua & 0.01 & 7,72 \\
Kota Kupang & 0.02 & \\
\hline
\end{tabular}

Keterangan: SS bernilai positif dan LQ lebih dari satu.

Berdasarkan analisis Tipologi Klassen yang memadukan analisis LQ dan SS dalam menentukan wilayah mana yang menjadi unggulan pengembangan ternak domba adalah sebagai berikut:

1. Kuadran I (SS $(+)$ dan LQ $>1)$ terdiri dari wilayahwilayah Kabupaten Sabu Raijua dan Rote Ndao.

2. Kuadran II $(\mathrm{LQ}<1$ dan SS $(+))$ terdiri dari wilayahwilayah Kabupaten Sikka, Ngada, Flores Timur, Sumba Timur, Kupang, Lembata, Kota Kupang.

3. Kuadran III (LQ > 1 dan SS (-)) tidak ada wilayahnya

4. Kuadran IV (LQ $<1$ dan SS (-)) terdiri dari wilayahwilayah Kabupaten Timur Tengah Utara.

Berdasarkan hasil analisis Tipologi Klasen tersebut, ada dua kabupaten yang menjadi wilayah unggulan ternak domba, yaitu Kabupaten Rote Ndao dan Sabu Raijua. Kedua kabupaten ini, selain memiliki comparative dan competitive advantage, juga memiliki iklim yang cocok usaha ternak domba. Kedua kabupaten ini merupakan kabupaten paling selatan di provinsi ini. Masing-masing merupakan pulau tersendiri. Secara historis, kedua kabupaten tersebut merupakan pulau bagi pengembangan ternak domba pada zaman penjajahan Belanda, sehingga masyarakatnya sudah terbiasa memelihara domba dan telah menjadi bagian dari budaya pertanian di kedua pulau tersebut.

Hasil analisis ini juga dapat dijadikan rujukan untuk penyusunan Rencana Tata Ruang Wilayah (RTRW) Provinsi Nusa Tenggara Timur. Berdasarkan Perda RTRW, belum ada penjelasan kawasan peternakan dan wilayahnya, khususnya tentang ternak domba, sehingga hasil dari kajian ini dapat dijadikan salah satu pertimbangan dalam penetapan kawasan peternakan domba di Provinsi Nusa Tenggara Timur.

\section{Penentuan Unggulan Ternak Babi di Provinsi NTT}

Ternak babi telah lama mejadi bagian budaya bagi petani di Nusa Tenggara Timur karena ternak ini memiliki nilai ekonomis dan sekaligus nilai religi. Daging babi sudah menjadi daging yang biasa dikonsumsi oleh masyarakat di provinsi ini. Oleh karena itu, daging babi memiliki nilai ekonomis dan juga NTT merupakan provinsi pensuplai kebutuhan daging babi bagi daerah lainnya.

Analisis dilakukan untuk menentukan wilayah mana yang memiliki keunggulan komparatif dan kompetitif untuk membangun peternakan babi di NTT. Keunggulan comparative ternak babi dianalisis dengan LQ. Perhitungan analisis untuk penentuan daya kompetisi ternak di suatu wilayah, dianalisia dengan analisis SS.

Tabel 3. Hasil Analisis LQ dan SS Ternak Babi

\begin{tabular}{lcc}
\hline \multicolumn{1}{c}{ Kabupaten/Kota } & \multicolumn{2}{c}{ Nilai } \\
\cline { 2 - 3 } & SS (+) & LQ (>1) \\
\hline Sumba Barat & 0.03 & 1,29 \\
Sumba Timur & 1.41 & \\
Kupang & 0.90 & 1,24 \\
Timor Tengah Selatan & 0.03 & 1.19 \\
Belu & & 1.06 \\
Alor & 0.03 & \\
Flores Timur & 0.03 & \\
Sikka & 0.03 & 1.13 \\
Ngada & 0.03 & \\
Rote Ndao & 0.03 & 1,09 \\
Sumba Tengah & 0.03 & 1,11 \\
Sumba Barat Daya & 0.55 & \\
Nagekeo & 0.03 & 1.05 \\
Manggarai & & 1.16 \\
Manggarai Barat & & \\
Manggarai Timur & 0.03 & \\
Malaka & & \\
Sabu Raijua & 0.03 & \\
Kota Kupang & & \\
\hline
\end{tabular}

Keterangan: SS bernilai positif dan LQ lebih dari satu.. 
Berdasarkan Tabel 3, hasil analisis LQ untuk ternak babi menujukkan bahwa hanya terdapat 11 wilayah yang merupakan basis ternak babi. Wilayah dengan nilai LQ terbesar adalah Kabupaten Sumba Barat, sedangkan LQ yang terkecil namun masih di atas satu adalah Kabupaten Manggarai. Hasil LQ ini membuktikan bahwa ternak babi menjadi komoditas basis dan merupakan bagian dari usaha peternakan di 11 wilayah tersebut. Babi merupakan komoditas ternak yang telah membudaya di Provinsi NTT. Akan tetapi, tidak semua wilayah dapat dikategorikan sebagai wilayah unggulan untuk ternak babi.

Hasil analisis SS diperlihatkan pada Tabel 3. Pada tabel tersebut wilayah-wilayah yang memiliki SS $(+)$ untuk ternak babi ada 15 wilayah. Berdasarkan perhitungan SS, jumlah wilayah yang mempunyai keuntungan kompetitif lebih banyak dibandingkan dengan hasil LQ. Artinya, ke 15 wilayah tersebut secara relatif memiliki kemampuan untuk mengekspor ternak babinya ke luar wilayah lain. Adapun nilai SS yang terbaik untuk ternak babi adalah di Kabupaten Sabu Raijua dengan nilai SS sebesar 1,56 yang diikuti oleh Kabupaten Sumba Timur dan Kabupaten Kupang. Ternak babi di Kabupaten Sabu Raijua dan Kabupaten Sumba Timur lebih memiliki keunggulan kompetitif dibandingkan dengan kabupaten/kota lainnya di Provinsi NTT karena memiliki nilai SS positif lebih dari satu. Hal ini dapat membuktikan bahwa ternak babi untuk Kabupaten Sumba Teimur dan Sabu Raijua memiliki keunggulan kompetitif dibandingkan dengan wilayahwilayah lainnya.

Hasil Tipologi Klassen untuk wilayah pengembangan ternak babi adalah sebagai berikut:

1. Kuadran I (SS $(+)$ dan LQ $>1$ ) terdiri dari wilayahwilayah Kabupaten Sumba Tengah, Sumba Barat Daya, Sumba Barat, Timor Tengah Selatan, Ngada, Kupang, Kota Kupang.

2. Kuadran II $(\mathrm{LQ}<1$ dan SS $(+))$ terdiri dari wilayahwilayah Kabupaten Sumba Timur, Alor, Flores Timur, Sikka, Rote, Nagekeo, manggarai Timur, Sabua Raijua

3. Kuadran III (LQ > 1 dan SS (-)) terdiri dari wilayahwilayah Kabupaten Belu, Manggarai, Manggarai Barat

4. Kuadran IV (LQ $<1$ dan SS (-)) terdiri dari wilayahwilayah Kabupaten Timor Tengah Utara, Lembata, Ende.

Ada 10 wilayah yang memiliki keunggulan komparatif dan kompetitif yang digambarkan di Kuadaran I, yaitu Kabupaten Sumba Barat, Sumba Tengah, Sumba Barat Daya, Kupang, Timur Tengah Selatan (TTS), Ngada, dan Kota Kupang. Kota Kupang merupakan satusatu wilayah kota yang dapat dijadikan sebagai sentra pengembangan ternak babi di Provinsi NTT.

Hasil Tipologi Klasen ini dapat dijadikan rujukan untuk penyusunan Rencana Tata Ruang Wilayah
(RTRW) Provinsi Nusa Tenggara Timur. Berdasarkan Perda RTRW Provinsi Nusa Tenggara Timur tidak ada penjelasan berkenaan dengan kawasan peternakan babi dan wilayahnya, padahal ternak babi merupakan ternak unggulan di wilayah ini. Oleh karena itu, hasil kajian ini bisa digunakan sebagai salah satu acuan bagi revisi RTRW ke depan untuk penetapan kawasan peternakan babi komoditas babi di Provinsi Nusa Tenggara Timur

\section{SIMPULAN}

Berdasar hasil penjelasan pada uraian sebelumnya, dapat disimpulkan bahwa daerah-daerah yang dapat dijadikan sentra pengembangan ternak kecil adalah sebagai berikut: Pengembangan ternak kambing terdapat di Kabupaten Sumba Timur, Timur Tengah Utara (TTU), Alor, Nagekeo, Manggarai Timur, Flores Timur, Sikka, dan Sabu Raijua; Pengembangan ternak domba terdapat di Kabupaten Rote Ndao dan Sabu Raijua; Pengembangan ternak babi terdapat di Kabupaten Sumba Barat, Kupang, Timur Tengah Selatan (TTS), Ngada, Sumba Tengah, Sumba Barat Daya, dan Kota Kupang.

\section{DAFTAR PUSTAKA}

Adisasmita, R. (2005) Dasar-Dasar Ekonomi Wilayah. Yogyakarta : Graha Ilmu.

Ariana I.N.T., Puger A.W., Oka A.A., \& Sriyani N.L.P. (2014) Analisis Ekonomi Usaha Ternak Babi Dengan Pemberian Sekam Padi Dalam Ransum yang Mengandung Limbah Hotel. Majalah Ilmiah Peternakan, 17, (2), 71-74.

Arsyad, L, (2005) Pengantar Perencanaan Pembangunan Ekonomi Daerah Edisi Kedua. Yogyakarta : BPFE.

Bappeda Kutai Kartanegara. (2008) Shift Share. http:// www. bappedakutaikartanegara.go.id/simreda/ shiftshare.html.

Budiarsana, I.G.M, Wibowo, B, \& Priyanto, D. (2016) Produktivitas dan Rantai Pasok Ternak Kambing dan Domba (KADO) Studi Kasus di Kabupaten Tegal. Jurnal Ilmu Ternak, 16, (2), 35-42.

Deny (2016). Sumber Daya Genetik Domba Lokal Potensial Indonesia dari Pulau Sabu, Nusa Tenggara Timur (NTT). https://www.bankselgamet. com/2016/10/31/sumber-daya-genetik-dombalokal-potensial-indonesia-dari-pulau-sabu-nusatenggara-timur-ntt/ diakses tanggal 12 Agustus 2019

Eliza. (2017) Kontribusi Sektor Transportasi Terhadap Perekonomian Daerah Di Provinsi Sumatera Barat. Jurnal Plano Madani, 6, (2), 177 - 184. 
Firman, A. (2003). Peranan Perkebunan Rakyat dalam Pembangunan Wilayah dan Penanggulangan Kemiskinan di Kabupaten Pinrang Propinsi Sulawesi Selatan. Tesis Pascasarjana Ekonomi Pertanian, Institut Pertanian Bogor. Bogor.

Food and Agriculture Organization (FAO). (2002) Conserving and Developing Farm Animal Diversity. Rome: Secretariat of The Report on The State of The Word's Animal Genetic Resources. FAO. Roma.

Hendayana, R. (2003). Aplikasi Metode Location Quotient dalam Penentuan Komoditas Unggulan Nasional. Informatika Pertanian, 2, 1-21.

Jarmuji. (2010). Produksi Susu Induk Terhadap Pengaruh Pertambahan Bobot Badan, Bobot Sapih Dan Daya Hidup Anak Domba Ekor Tipis Jawa Periode Prasapih. Jurnal Sain Peternakan Indonesia, 5, (1), 1-8.

Pemda Kabupaten Timor Tengah Selatan (2019). Peternakan. http://tskab.go.id/potensi-daerah/ peternakan/. Diakses tanggal 12 Agustus 2019.

Riadi, D.M.M. (2000). Pembangunan Daerah Melalui Pengembangan Wilayah. Disampaikan pada Acara Diseminasi dan Diskusi Program-Program Pengembangan Wilayah dan Pengembangan Ekonomi Masyarakat di Daerah, Bogor, 15-16 Mei 2000.

Riwu, A.R (2017). Kajian Keragaman Fenotipik Domba Ekor Gemuk (Deg) Di Nusa Tenggara Timur. Proceeding Book: Seminar Nasional Ke 2, Hasil Penelitian dan Pengabdian Kepada Masyarakat. Fakultas Peternakan dan Fakultas Kedokteran Hewan, Universitas Brawijaya Malang, 23-41.

Rothschild, M.F., Ruvinsky, A., Larson, G., Gongora, J., Cucchi, T., Dobney, K., Andersson, L., Plastow, G., Nicholas, F.W. \& Moran, C. (2011) The genetics of the pig. 2nd ed. Rothschild MF, Ruvinsky A, editors. London: $\mathrm{CAB}$ International.
Sambodo, M.T., (2002). Analisis Sektor Unggulan Propinsi Kalimantan Barat. Jurnal Ekonomi dan Pembangunan, 10 (2). Pusat Penelitian Ekonomi Lembaga Ilmu Pengetahuan Indonesia. Jakarta

Sapriadi \& Hasbullah. (2015) Analisis Penentuan Sektor Unggulan Perekonomian Kabupaten Bulukumba. Jurnal Iqtisaduna, 1, (1), 71-86.

Silaban, L.H., Edwina, S. \& Eliza. (2015). Analisis Sektor Basis Dan Perkembangan Sektor Pertanian Di Kabupaten Indragiri Hilir Provinsi Riau Tahun 2008-2012. Jurnal Faperta Riau. 2, (1), 1-9.

Suryadi, D., Rahayu, S., Firmansyah, C. \& Kuswaryan, S. (2016) Preferensi Konsumen Terhadap Daging Domba Di Jawa Barat. Sosiohumaniora, 18, (1), 27-33. https://doi.org/10.24198/sosiohumaniora. v18i1.9353

Susanto, H. (2014). Kajian Komoditas Unggulan, Andalan dan Potensial di Kabupaten Grobogan. Journal of Rural and Development, 5, (1), 65-80.

Suwardi, B.D.P. \& Thalib, C. (2015) PengembanganTernak Babi Lokal di Indonesia. WARTAZOA, 25, (1), 39-46. http://dx.doi.org/10.14334/wartazoa. v25i1.1127

Juarini, E., Sumanto., Wibowo, B., \& Suratman. (2011) Daya Dukung Hijauan Pakan untuk Pengembangan Ternak Sapi Potong dan Kerbau dalam Mendukung PSDS/K Tahun 2014 di Kabupaten Lebak. Seminar Nasional Teknologi Peternakan dan Veteriner. Pusat Penelitian dan Pengembangan Peternakan, Kementerian Pertanian.

Widjaya, D.S.M. (2012) Analisis Penentuan Sektor Unggulan Perekonomian Wilayah Kabupaten Ngawi. Tesis Program Pascasarjana Ekonomi dan Studi Pembangunan, Fakultas Ekonomi, Universitas Sebelas Maret. Surakarta.

Wea, R. (2016) Performans Produksi dan Reproduksi Ternak Babi Lokal di Kodya Kupang. Jurnal Partner, 16, (1), 21-28. 